\title{
FY2018 - Output Cost Estimates and Budget Outturn
}




\section{FY2018-OUTPUT COST ESTIMATES AND BUDGET}

\section{OUTTURN}

IMF staff regularly produces papers proposing new IMF policies, exploring options for reform, or reviewing existing IMF policies and operations. The Report prepared by IMF staff and completed on July 23, 2018, has been released.

The staff report was issued to the Executive Board for information. The report was prepared by IMF staff. The views expressed in this paper are those of the IMF staff and do not necessarily represent the views of the IMF's Executive Board.

The IMF's transparency policy allows for the deletion of market-sensitive information and premature disclosure of the authorities' policy intentions in published staff reports and other documents.

Electronic copies of IMF Policy Papers

are available to the public from

http://www.imf.org/external/pp/ppindex.aspx

\section{International Monetary Fund Washington, D.C.}




\section{INTERNATIONAL MONETARY FUND}

July 23, 2018

\section{FY2018-OUTPUT COST ESTIMATES AND BUDGET} OUTTURN

\section{EXECUTIVE SUMMARY}

The Fund continues to make efforts to maximize the use of available resources in order to deliver on the priorities and initiatives laid out in the Global Policy Agenda (GPA). The FY 18 outturn reflects reallocations and efficiency gains, as well as flexibility provided by carry forward resources.

With the number of Fund arrangements falling, the Fund's outputs shifted from spending on lending activity to multilateral surveillance. On the input side, the structural budget was fully utilized.

This paper presents key highlights of the FY 18 outturn, including a discussion of the outputs and inputs. Details on Capacity Development (CD) are presented in Annex I. 
Approved By Daniel Citrin
Prepared by the Office of Budget and Planning (OBP) team with Piyabha Kongsamut as lead and including contributions from Rebecca Brofft, Melanie Burke, Vanessa Diaz Montelongo, Angeliki Economopoulos, Sepideh Khazai, Carolina Parodi, Anika Shtuni, Justin Tyson, Gisela Ulmschneider, Muriel Vimond, Barrie Williams, Talia Zhang and Jiu Hong Zhou. Annex I was contributed by Lidia Brito, Nathalie Carcenac, Felix Fischer, Yiruo Li, Mercy Pinargote, Wasima Rahman-Garrett, Yan Sun, and Andre Vieira de Carvalho (all ICD).

\section{CONTENTS}

FY2018 HIGHLIGHTS

OVERVIEW

SPENDING BY OUTPUT

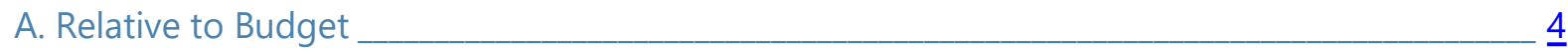

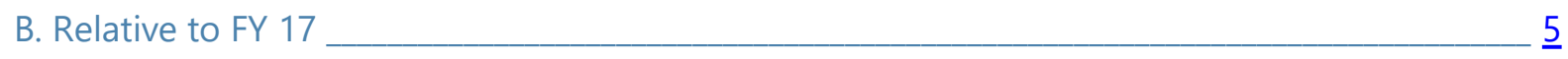

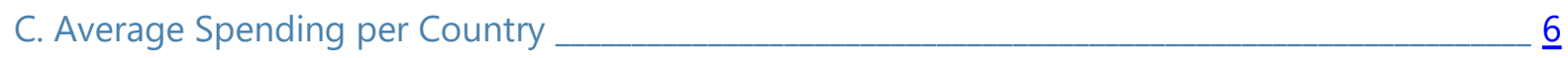

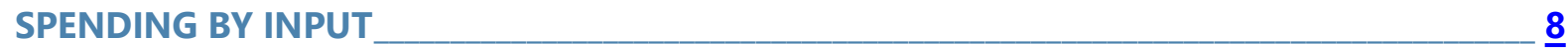

A. Fund-financed and Total Spending Relative to Budget ______ $\underline{8}$

B. Fund-financed Spending Relative to Total Available Resources____ $\underline{9}$

C. Total Spending on Inputs in Greater Detail ______

\section{FIGURES}

1. Change in Direct Spending on Multilateral Surveillance, Analytical Work, and Global

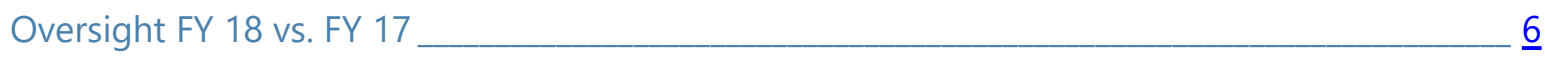

2. Average Spending per Country, FY 17-18________ $\underline{6}$

3. Available Resources and Use of Carry Forward, FY $18 \ldots$

4. Spending by Main Departments and Offices, FY $18 \ldots$

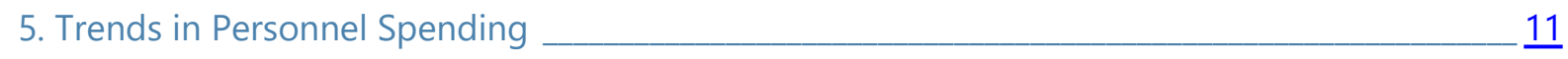

\section{TABLES}

1. Gross Administrative Fund-financed Resources: by Output, FY 16-18____ $\underline{4}$

2. Administrative Budget and Expenditures, FY 17-18______ $\underline{8}$

\section{ANNEXES}

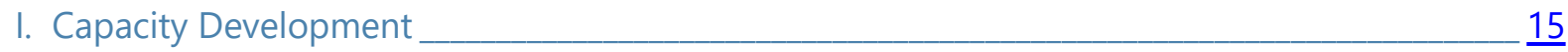

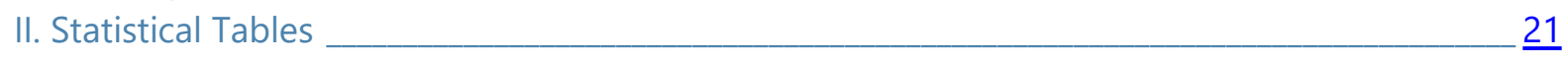




\section{FY2018 HIGHLIGHTS}

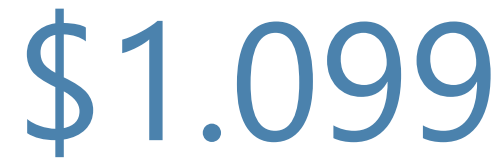

billion

Net administrative spending was virtually at budget, or 99.5 percent utilization, compared with 99.4 percent in FY 17. Relative to total net available resources (including carry forward), the utilization rate was 95.7 percent.

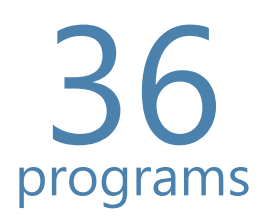

This represents a decline in the number of active programs (General Resources Account (GRA), Poverty Reduction and Growth Trust (PRGT), and Policy Support Instrument (PSI)) of 16 percent, from 43 active programs at end FY 17. Spending on lending fell accordingly.

Average spending per country. Country work (excluding regional technical and training centers) represents 47 percent of total direct spending.
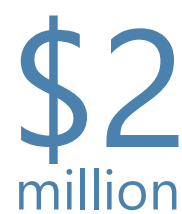

\section{$\$ 174$}

million

Externally financed CD activities grew by 14 percent in FY 18.

Carry forward available for FY 19 to meet transitional needs; $\$ 31$ million for staff departments and the remainder for Office of Executive Directors (OED) and Independent Evaluation Office (IEO).

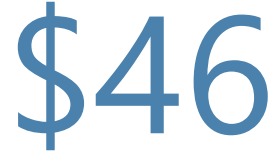

million

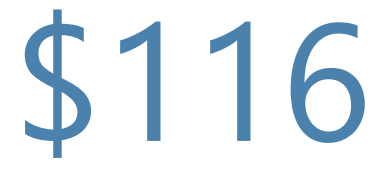

million
Capital spending. Around half for HQ1 renewal, 27 percent for information technology projects, and the remainder for building facilities and audio-visual work.

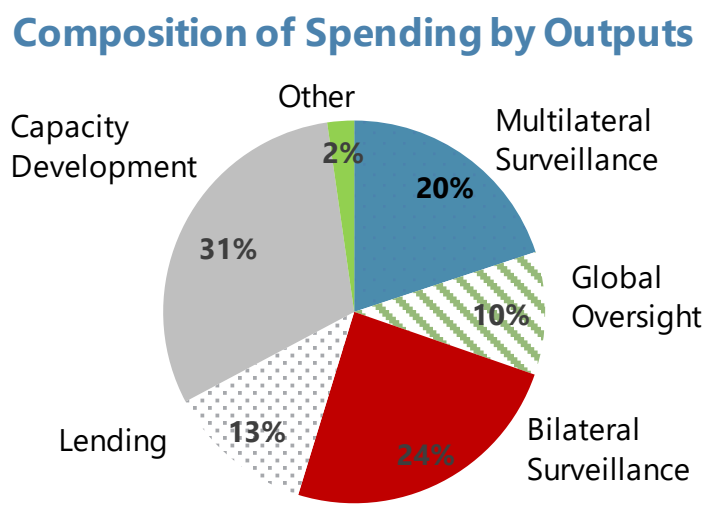

Note: Support and governance costs included in outputs.

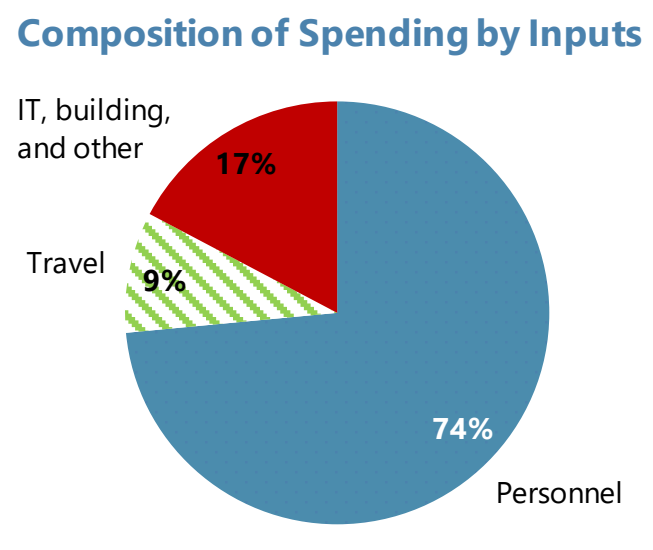




\section{OVERVIEW}

Spending was in line with the priorities laid out in the GPA, while remaining within the envelope of a flat real budget. In FY 18, there was a shift towards cross-country analytical and policy work, while spending on lending activities fell. The overall net administrative outturn was within the approved budget, with an execution rate of close to 100 percent, similar to last year. Relative to total net available resources (including structural and carry forward), the execution rate was 95.7 percent.

\section{SPENDING BY OUTPUT ${ }^{1,2}$}

\section{A. Relative to Budget}

1. Spending in FY 18 was in line with the strategic priorities set in the FY 18-20 Medium-Term Budget (MTB), except for lower than planned spending on lending and near-lending activities (Table 1). The FY 18-20 MTB set out the following output priorities: a shift from surveillance to lending as more countries were expected to request programs; continuing support for financial sector surveillance; and policy and analytical work on structural issues and new challenges. The budget expected intensified program work, which materialized in the African department (AFR) while declining in other departments (see below). Resources were provided to support macro-financial

\begin{tabular}{|c|c|c|c|c|}
\hline \multicolumn{5}{|c|}{$\begin{array}{l}\text { Table 1. Gross Administrative Fund-fin } \\
\text { Resources: by Output, FY 16-18 } \\
\text { (Millions of FY } 18 \text { U.S. dollars) }\end{array}$} \\
\hline & \multirow[b]{2}{*}{$\begin{array}{l}\text { FY } 16 \\
\text { Outturn }\end{array}$} & \multirow[b]{2}{*}{$\begin{array}{c}\text { FY } 17 \\
\text { Outturn }\end{array}$} & \multicolumn{2}{|c|}{ FY 18} \\
\hline & & & $\begin{array}{l}\text { Estimated } \\
\text { Resources }\end{array}$ & Outturn \\
\hline Total & 1,127 & 1,137 & 1,143 & 1,140 \\
\hline Multilateral Surveillance & 168 & 166 & 167 & 171 \\
\hline Oversight of Global Systems & 84 & 86 & 88 & 87 \\
\hline Bilateral Surveillance & 199 & 204 & 205 & 205 \\
\hline Lending & 124 & 112 & 115 & 107 \\
\hline Capacity Development & 136 & 136 & 138 & 138 \\
\hline Support and Governance & 371 & 378 & 391 & 402 \\
\hline Miscellaneous 1/ & 29 & 27 & 28 & 22 \\
\hline Contingency & $\ldots$ & $\ldots$ & 11 & $\ldots$ \\
\hline Reconciliation item 2/ & 17 & 27 & $\ldots$ & 8 \\
\hline \multicolumn{5}{|c|}{$\begin{array}{l}\text { Source: Office of Budget and Planning, Analytic Costing and Estimation System (ACES) } \\
\text { 1/ The "Miscellaneous" classification covers expenditures that currently cannot be } \\
\text { allocated to specific outputs within the ACES model. } \\
\text { 2/ Difference between output-based ACES expenditures and input-based gross } \\
\text { administrative expenditures as per the Fund's financial system. }\end{array}$} \\
\hline
\end{tabular}
mainstreaming, and for macro-structural and fiscal space policy and country work.

\footnotetext{
${ }^{1}$ This section describes the main trends in spending observed using the Analytic Costing and Estimation System (ACES), which has been in use since FY 11. The ACES model takes the Fund's input costs and allocates them to outputs, with the single most important input being self-reported time. Support and governance costs are tracked as intermediate inputs that feed into the production of outputs. For details on ACES, see "FY2015 Administrative and Capital Expenses and Output Cost Estimates", Box 2.

${ }^{2}$ In developing ACES, a balance was struck between precision (for meaningful results) and complexity (to not overburden staff in their time reporting). The goal of mapping at least 95 percent of gross administrative expenditures to a final output has been achieved. Nevertheless, efforts continue to narrow the differences between the Fund's financial system and ACES data, including in "Miscellaneous" and the reconciliation item (see Table 1).
} 


\section{Spending on support and governance continued to experience pressure, some of which}

was anticipated. This includes priority areas for transforming IT and HR services, and enhanced risk mitigation and knowledge management (KM), as the KM unit was established to support cross-country analysis and knowledge transfer.

\section{B. Relative to FY 17}

\section{Spending on lending declined, offset by an increase in multilateral surveillance; greater use of external financing boosted CD spending.}

- The real decline in spending on lending of around $\$ 5$ million was offset by an increase in spending on multilateral surveillance of a similar magnitude. Externally-financed $C D$ increased by $\$ 27$ million, reflecting improved execution, additional experts in the field, and also improved measurement. ${ }^{3}$

- Despite an increase in spending on lending for new programs in Africa, there was lower spending on lending overall. This reflects countries exiting from programs or engaging less intensively through non-financial instruments ${ }^{4}$ in Europe, Latin America and the Caribbean, and other countries in Africa.

- Lending declined by more than the increase in bilateral surveillance because of a shift to multilateral surveillance and $C D$ in functional departments, and because spending on Financial Sector Assessment Programs (FSAPs) declined after a peak in the cycle of systemic FSAPs.

- CD growth was seen in all Technical Assistance (TA) functional departments except ICD (Annex I). The decline in the Institute for Capacity Development's (ICD) CD spending is largely due to a change in the administration of $C D$ spending that shifted some expenditures to the other TA functional and area departments.

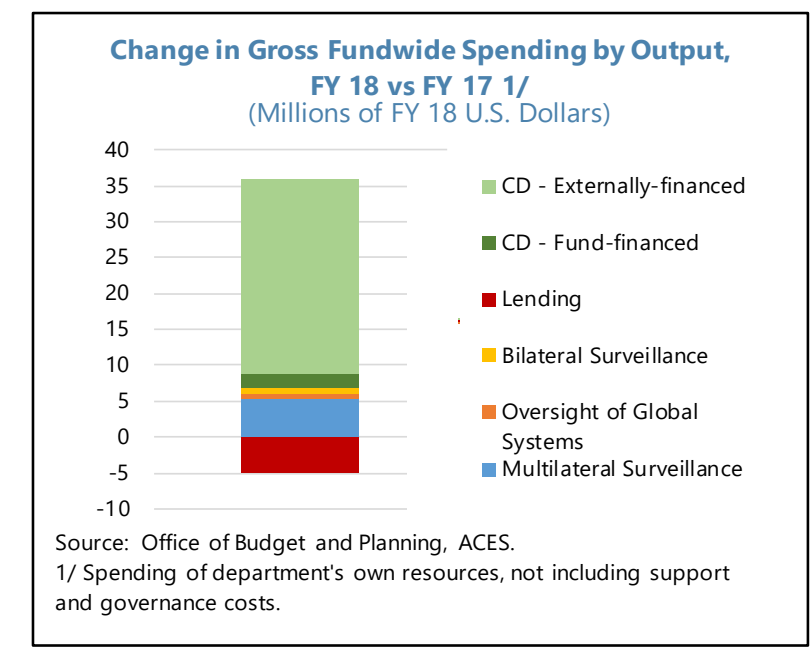

Change in Direct Spending on Country Work, FY 18 vs. FY 17 1/ (Millions of FY 18 U.S. dollars) $\begin{array}{llllllllll}-15 & -10 & -5 & 0 & 5 & 10 & 15 & 20 & 25 & 30\end{array}$

Article IV and other bilateral surv.

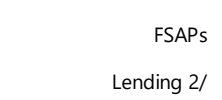

FSAPs

Lending 2/

Capacity development

Source: Office of Budget and Planning, ACES.

1/ Spending of department's own resources on both Fund-financed (IMF01) and externally-financed (IMF02) activities.

2/ Exit from program (green), new program (red), and no change in status (yellow).

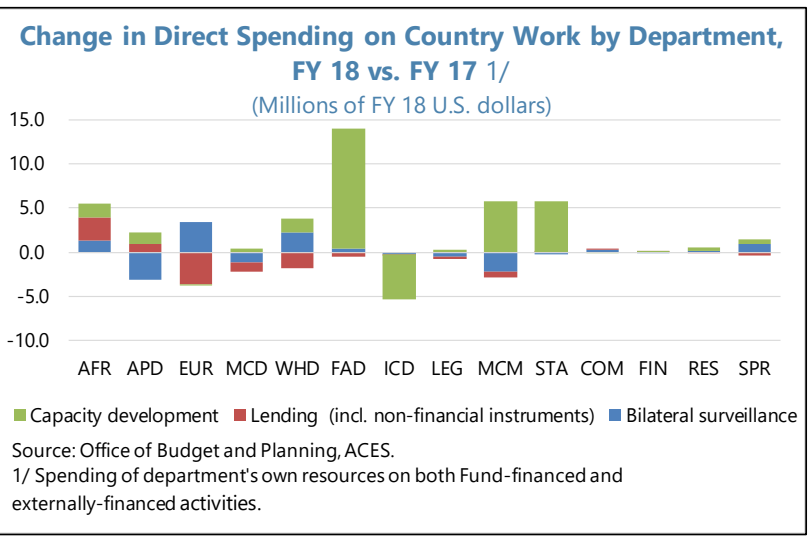

\footnotetext{
${ }^{3}$ Changes in source data led to an additional $\$ 13$ million of externally-financed CD expenditures in FY 18 being captured by ACES. Most of it related to time reported by experts outside the system as well as centrally managed expenses for field offices, including training activities.

${ }^{4}$ Such as PSI, Post Program Monitoring (PPM), Staff Monitored Program (SMP), or near program status.
} 


\section{The increase in multilateral surveillance spending reflects more work on cross-cutting} issues, non-WEO flagships, vulnerabilities and imbalances, and regional surveillance (Figure 1). Policy work shifted along with the cycle of reviews, in line with the Board's Work Program.

- The increase in multilateral surveillance reflects work on the External Balance Assessment (EBA) and EBA-lite methodologies (seen in risk, vulnerabilities, and imbalances), crosscutting analytical work in area departments and the Research department (RES), projects at a regional level, and the GFSR and Fiscal Monitor.

- Within global oversight, policy work

Figure 1. Change in Direct Spending on Multilateral Surveillance, Analytical Work, and Global Oversight FY 18 vs. FY 17 1/

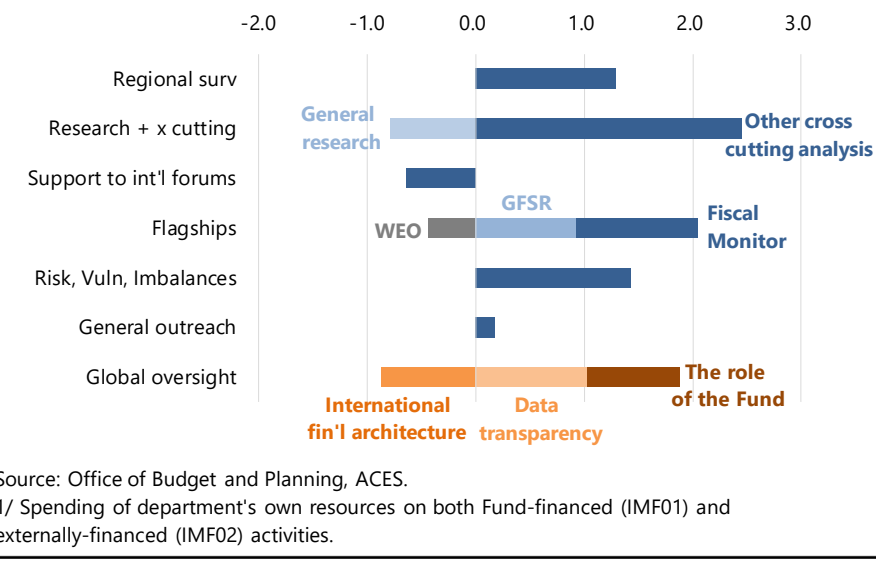
shifted from the Global Financial Safety Net to other policy reviews (Interim Surveillance Review, Multiple Currency Practices, CD strategy) and data transparency issues.

\section{Average Spending per Country}

5. Resource allocation across countries continues to be risk-based, while spending on fragile states is on par with average per country spending for members under intensive surveillance.

- Average spending per country is broadly stable, at around $\$ 2$ million (Figure 2). This masks differences in spending according to risk, as measured by program or vulnerability status. Spending on surveillance countries is below that on program and vulnerable countries.

- The average program country spend increased to $\$ 3.2$ million in FY 18, driven mainly by increased $C D$. The difference between average spending on vulnerable program countries and program countries in general declined in FY 18, as the intensity of engagement in a number of vulnerable program countries fell.

- Spending on fragile states is around as much on average as for intensive surveillance countries; around \$2.2-2.3 million in FY 17 and 18. This category spans a wide range of country sizes and circumstances, such as small islands, high security risk locations, surveillance as well as program countries, and different vulnerability status. Spending on these countries varies as widely, though average and median spending are close to each other. More than half of the fragile states exceed $\$ 2$ million per year.
Figure 2. Average Spending per Country, FY 17-18

(Direct cost in millions of FY 18 U.S. dollars)

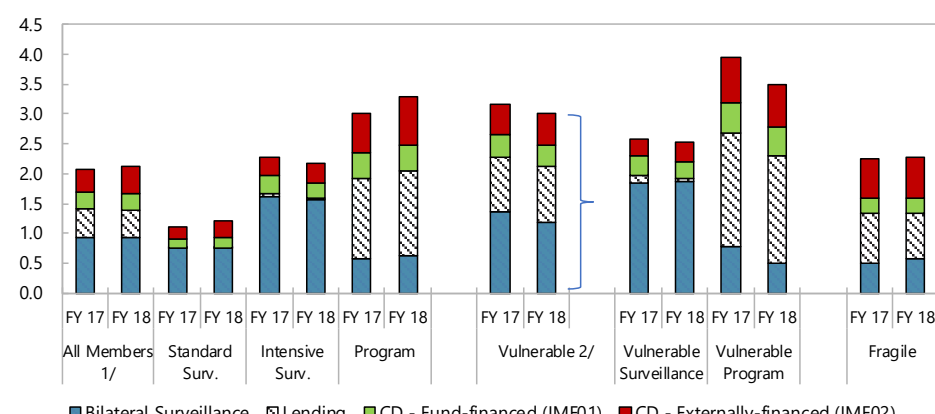

Source: Office of Budget and Planning, ACES.

1/ Includes spending that is attributed specifically to individual member countries, territories or regional bodies, and therefore excludes some spending by the regional technical assistance or training centers.

2/ Vulnerable and Fragile are a subset of, and overlap with, all main groupings. 


\section{Average spending per country is highest for African economies and low-income countries.}

- Spending on countries in AFR is higher on average than other regions, reflecting the costs of lending and CD.

- Other regions average between $\$ 1.8$ to $\$ 2.1$ million per country, with the mix between surveillance, lending and $C D$ depending on country status.

- By country grouping, spending on low-income countries averaged $\$ 2.8$ million per country, with a high share of lending and CD. Average spending on emerging market countries was lower at $\$ 2.3$ million, and advanced economies averaged $\$ 1.6$ million. Higher average spending on G-20 countries reflects FSAPs which were conducted in many G-20 countries in the past two years (e.g. Brazil, China, Euro area, Saudi Arabia).

7. Drivers of costs vary across outputs, with travel and governance costs showing the largest differences.

- As expected, with 70 percent of the budget spent on personnel, the labor share is the key cost driver for all output groups.

- Travel costs vary with the number of missions, with multilateral surveillance the lowest and $C D$ the highest.

- $C D$ has the lowest governance costs, as the Board sets overall CD strategy but does not discuss individual countries' TA reports.

- With new Regional CD Centers (RCDS) in place (e.g., SARTTAC) and spending from thematic vehicles, FY 18 saw an increase in the share of field spending on $C D$. The share of other input components across output categories remained stable compared to FY 17.
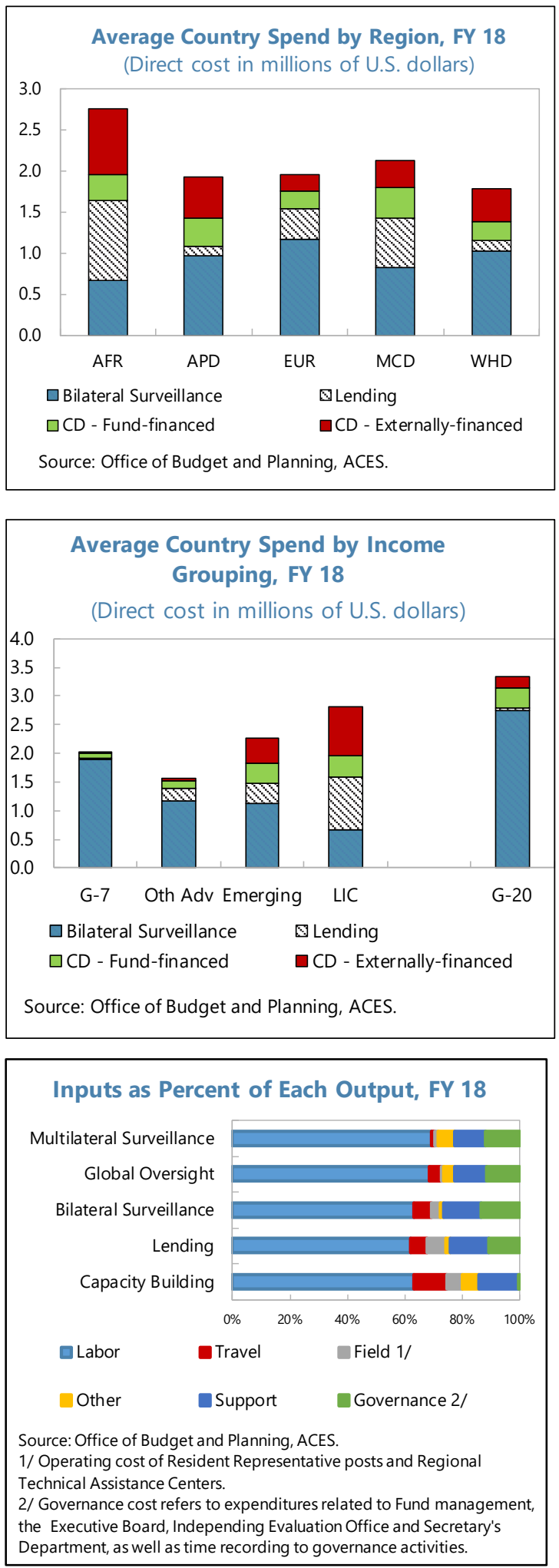


\section{SPENDING BY INPUT}

\section{A. Fund-financed and Total Spending Relative to Budget}

8. Total Fund-financed net administrative expenditures ended the year exactly at the approved structural budget of $\$ \mathbf{1 , 1 0 4}$ million (Table 2). With actual spending at the approved budget, the full FY 18 carry forward is available as envisaged in the FY2019-2021 medium-term budget paper.

- Personnel spending ended the year at budget. A slightly higher spending on contractual resources offset the underspend from staff vacancies.

- Travel spending fell short of budget by $\$ 5$ million mainly due to mission delays in Functional TA departments.

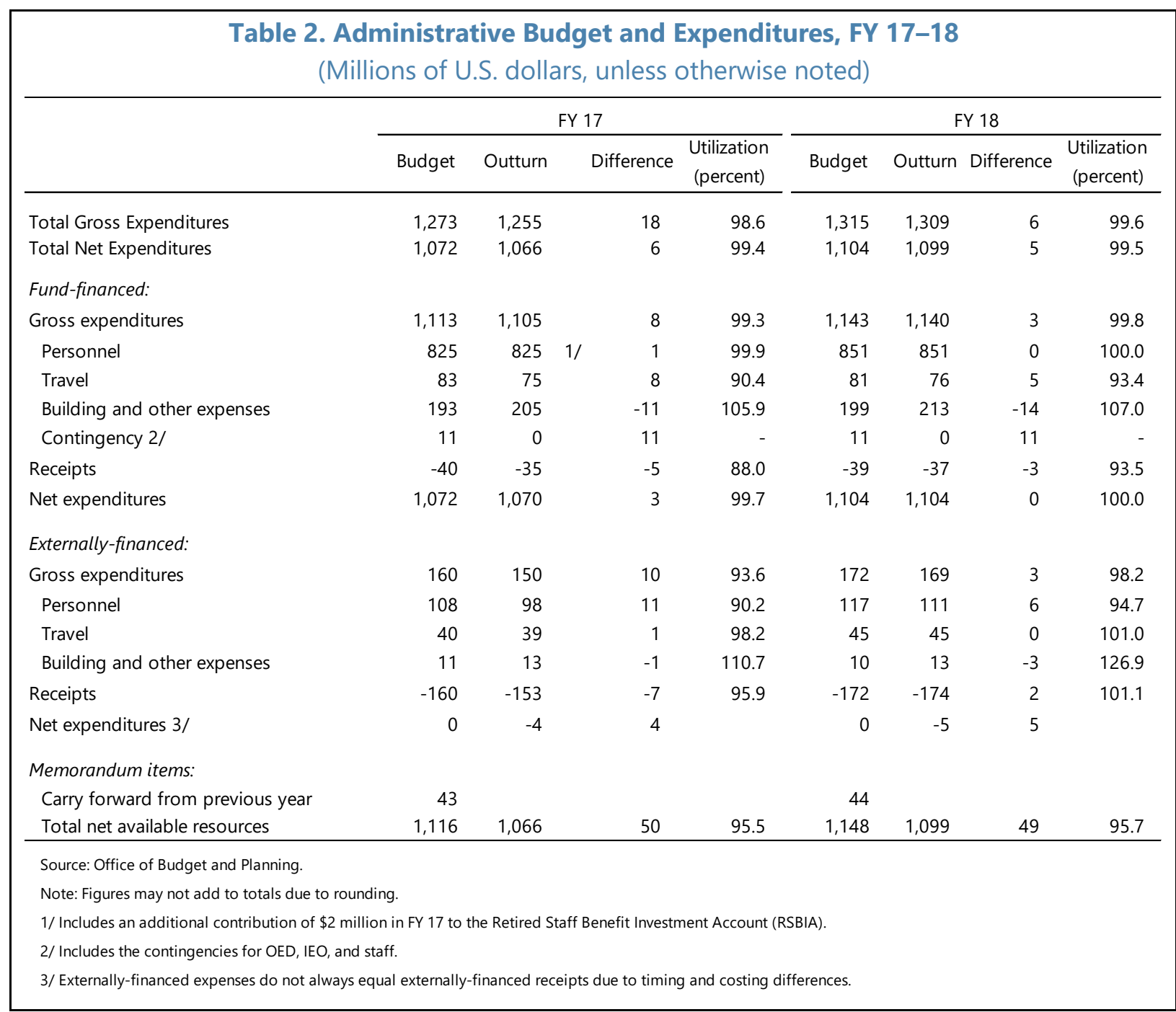


- Spending on building and other services exceeded the structural budget by $\$ 14$ million. This was largely anticipated and funded by an upfront allocation of the carry forward. The additional spending related to a range of needs, mainly: field office leases, high demand for language services, contractual services related to the review of compensation and also of the HR strategy, and transition costs for TransformIT initiatives. ${ }^{5}$

- A \$3 million shortfall in Fund-financed receipts relates to lower-than-planned income and reimbursements under the cost-sharing agreements with the World Bank.

\section{Total net expenditures were below budget because of externally-financed activities.}

Externally funded receipts, and thus activities, were $\$ 2$ million above planned levels. Relative to last year, this represents an increase of close to 13 percent and reflects improved execution of CD. Gross externally financed expenditures are slightly below receipts due to timing and recording of revenues and expenditures (see Annex I).

\section{B. Fund-financed Spending Relative to Total Available Resources}

\section{In FY 18, execution against total available resources (structural plus carry forward} funds) was at $\mathbf{9 5 . 7}$ percent, similar to last year. $\$ 44$ million was carried over from FY 17 (Figure 3), of which $\$ 30$ million was available to staff departments (with the remainder for OED and IEO). \$21 million was distributed at the beginning of the year to provide flexibility in meeting transitional needs in departmental work programs. An additional $\$ 7$ million was distributed later during the year as Figure 3. Available Resources and Use of Carry Forward, FY 18

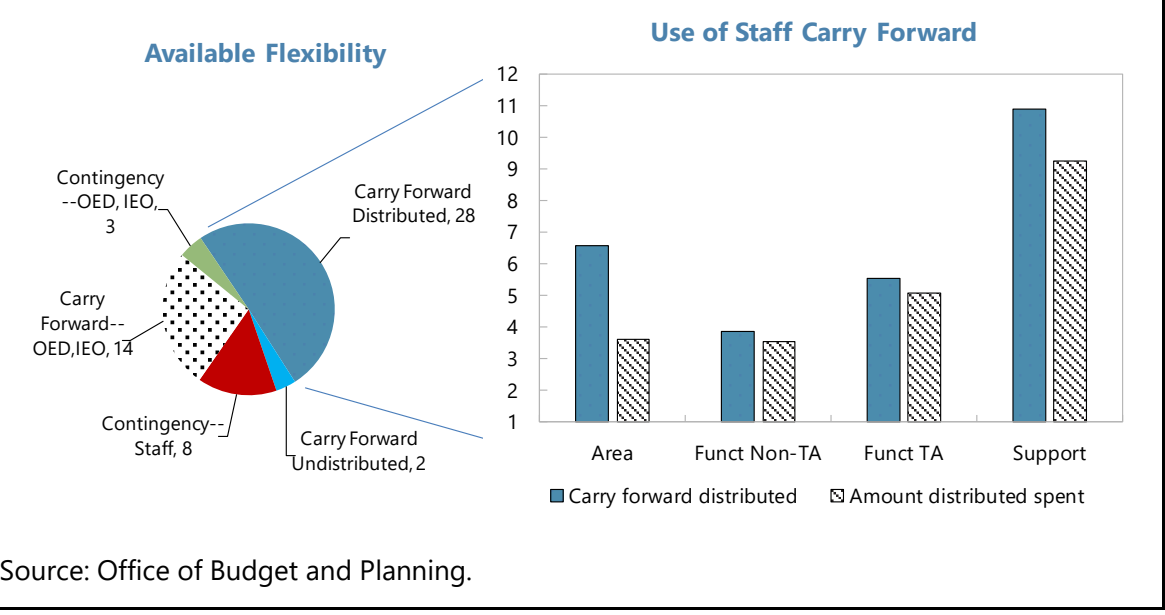
additional needs were anticipated. The use of staff carry forward varied by type of department, with functional departments spending almost all their allocated resources and area and support departments underspending their carry forward resources.

\footnotetext{
${ }^{5}$ TransformIT was initiated in FY 16, and aimed to change the Fund's IT operating model through greater agility, improved partnerships, and cost control and reduction. See Box 4 in the FY2018-FY2020 Medium Term Budget paper.
} 
11. The carry forward available for FY 19 remains largely the same, as the use of carry forward by some departments was offset by other departments underspending their total available resources (Figure 4). In FY 18, AFR used transitional funding to address pressures from new programs and an increase in intensive surveillance countries. The Strategy Policy and Review Department (SPR) provided increased support to AFR countries and the G-20 presidency, work on on fiscal space, trade, and debt. Meanwhile, the underutilization of allocated resources in the European Department (EUR) related to lower travel spending and vacancy lags, the postponement of Safeguards missions and vacancy lags in the Finance department (FIN), and the early closure of certain field offices in the Western Hemisphere

Figure 4. Spending by Main Departments and Offices, FY 18 (Millions of U.S. dollars)

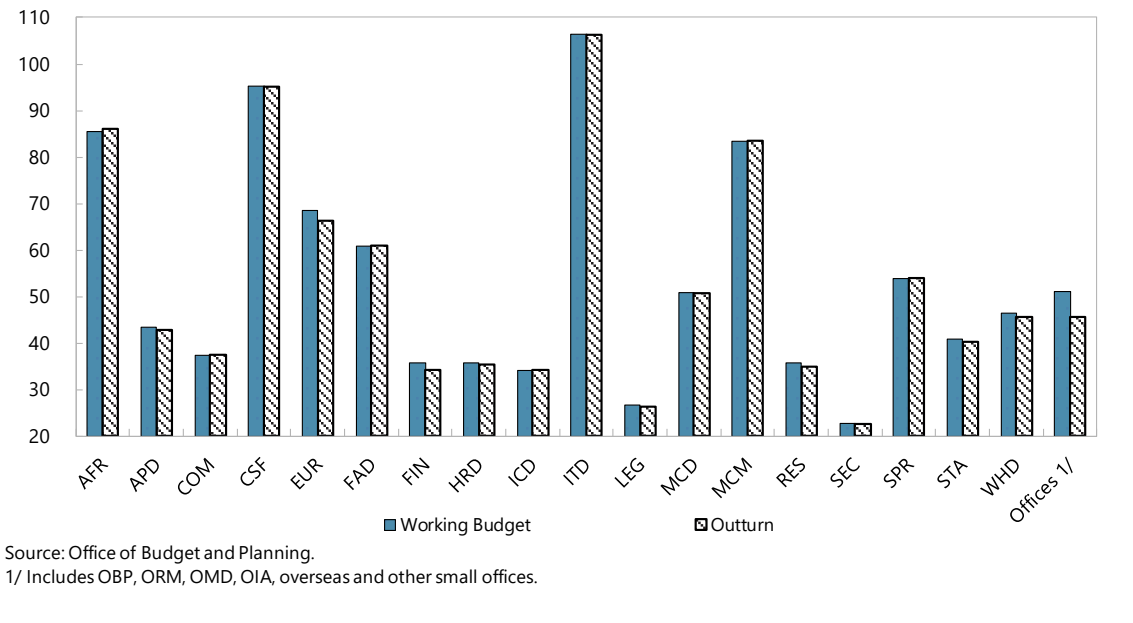

Department (WHD), partially offset the additional resources provided. Offices (Office of Budget and Planning, Office of Internal Audit, Office of the Managing Director, Office of Risk Management, and overseas and small offices), as well as unspent contingency funds in central accounts contributed to the underspend relative to total available resources.

\section{Total Spending on Inputs in Greater Detail}

\section{With regard to total personnel spending:}

- The personnel budget was almost fully utilized, representing an increase of 4.3 percent from FY 17, reflecting a 3 percent increase in Fund-financed and 14 percent in externally financed personnel expenditures. (Figure 5, panel 1).

- The average salary paid increased in line with the budget, with budget space generated for merit pay comparable to FY 17. 


\section{Figure 5. Trends in Personnel Spending}

The increase in overall staffing levels was primarily driven by externally-financed contractuals delivering $C D$, particularly short and long-term experts.

FTE Utilization, FY 16-18

\begin{tabular}{lrrrrr}
\hline & FY 16 & FY 17 & \multicolumn{2}{c}{ FY 18 } \\
\cline { 5 - 6 } & & & Budget & Outturn \\
\hline Total & 3,705 & 3,762 & $\ldots$ & 3,881 \\
$\quad$ Fund-financed & & & & \\
$\quad$ Regular and term & 2,767 & 2,813 & 2,867 & 2,836 \\
$\quad$ Expert and contractual 1/ & 556 & 556 & n/a & 586 \\
Externally-financed & & & & \\
$\quad$ Regular and term & 69 & 77 & 77 & 87 \\
$\quad$ Expert and contractual 1/ & 313 & 316 & n/a & 372 \\
\hline
\end{tabular}

Source: Office of Budget and Planning.

1/ Fund-financed and externally-financed experts (including short term),

contractuals, visiting scholars, secretarial support, and other
The overall vacancy rate remains low, at 1.4 percent. It is lower in frontline than in support departments.

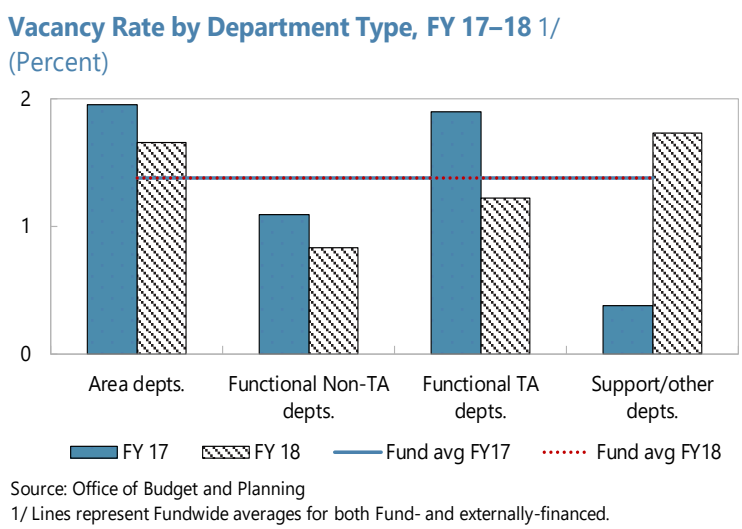

Contractual staffing growth (especially externally-financed) has been highly volatile; the decline in FY 16 reflects the impact of Categories of Employment reforms.

\section{Staffing levels \\ (Percent change)}

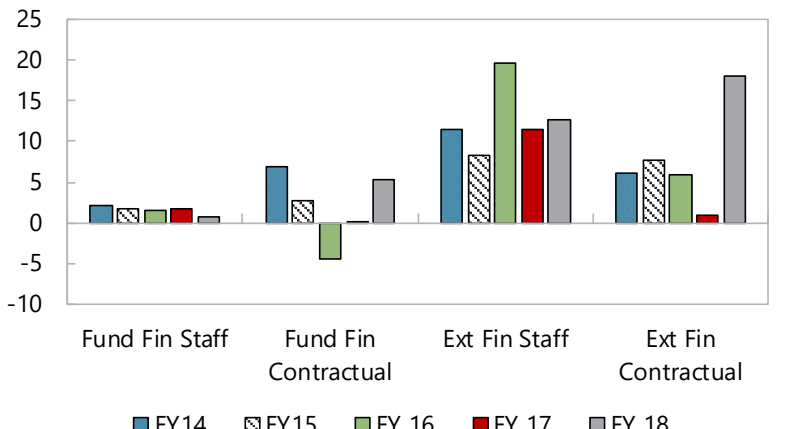

Source: Office of Budget and Planning

While the average overtime rate has stabilized at around

11 percent,

Average Fund-wide Overtime Rate Past 2 Years 1/

(Staff only, percent)

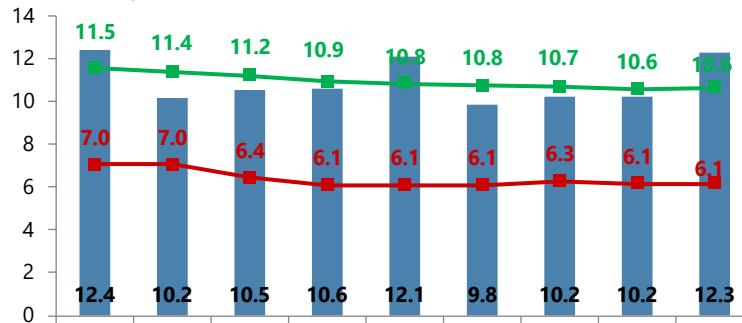

FY16 Q4 FY17 Q1 FY17 Q2 FY17 Q3 FY17 Q4 FY18 Q1 FY18 Q2 FY18 Q3 FY18 Q4 Overtime Rate

$=-4$ Quarter Moving Avg. Overtime Rate

-4 Quarter Moving Median Overtime Rate

Source: TRACES, TIMS, HRPROD.

1/ Data excludes regional offices. Expressed as percentage of actual hours worked

(i.e., regular hours minus leave).
... rates remain above the 15 percent threshold for most $B$ level staff.

Overtime Rate by Grade Group, FY 18 1/

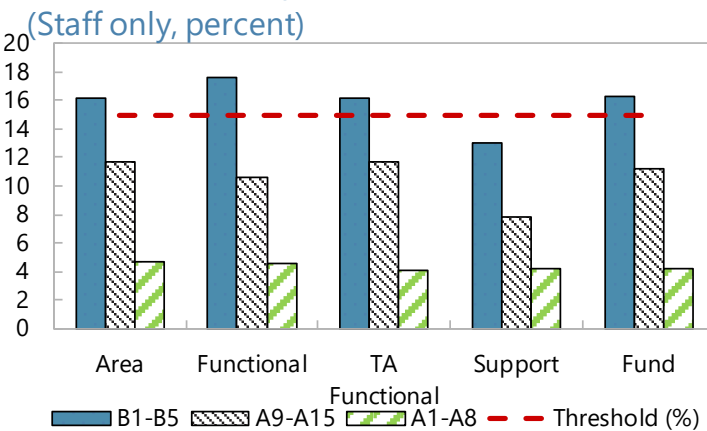

Source: TRACES, TIMS, HRPROD

1/ Data excludes regional offices. Expressed as a percentage of actual hours worked (i.e., regular hours minus leave). 
13. Spending on travel increased by 5 percent, reflecting both price and volume increases for business travel of around $21 / 2$ percent and $11 / 2$ percent, respectively.

- Utilization of the travel budget amounted to 96 percent. The small underspend of $\$ 5$ million was largely in Functional TA Departments (principally Fiscal Affairs Department and Statistics Department) due to mission delays.

- Volume growth in travel was mostly related to externally-financed missions, mirroring the trend of continued growth in externally financed $C D$ activities mainly in $F A D$, $M C M$, and STA.

- Growth was particularly prominent in $C D$ missions to Asia, which increased by 14 percent, as SARTTAC saw its first full year of operation. Countries that saw a significant increase included SARTTAC beneficiaries India, Bhutan and Sri Lanka.

- The average mission length fell from $11 \frac{1}{2}$ person days to 11 person days. ${ }^{6}$ This shift reflected the growth in share of TA Functional Department missions, which tend to have more frequent short duration missions relative to other department types (Annex II, Table 5).

\begin{tabular}{|c|c|c|c|c|}
\hline \multicolumn{5}{|c|}{$\begin{array}{c}\text { Travel, FY 16-18 } \\
\text { (Millions of U.S. dollars) }\end{array}$} \\
\hline & \multirow[t]{2}{*}{ FY 16} & \multirow[t]{2}{*}{ FY 17} & \multicolumn{2}{|c|}{ FY 18} \\
\hline & & & Budget & Outturn \\
\hline Expenditures & 120 & 115 & 126 & 121 \\
\hline Fund-financed & 81 & 75 & 81 & 76 \\
\hline Business travel & $641 /$ & 59 & 65 & 59 \\
\hline Seminars & 6 & 5 & 6 & 6 \\
\hline Other travel 2/ & 11 & 11 & 11 & 11 \\
\hline Externally-financed & 39 & 39 & 45 & 45 \\
\hline Business travel & 28 & 29 & 35 & 33 \\
\hline Seminars and other travel & 11 & 10 & 10 & 12 \\
\hline $\begin{array}{l}\text { Source: Office of Budget and Pla } \\
\text { Note: Figures may not add to to }\end{array}$ & ding. & & & \\
\hline
\end{tabular}

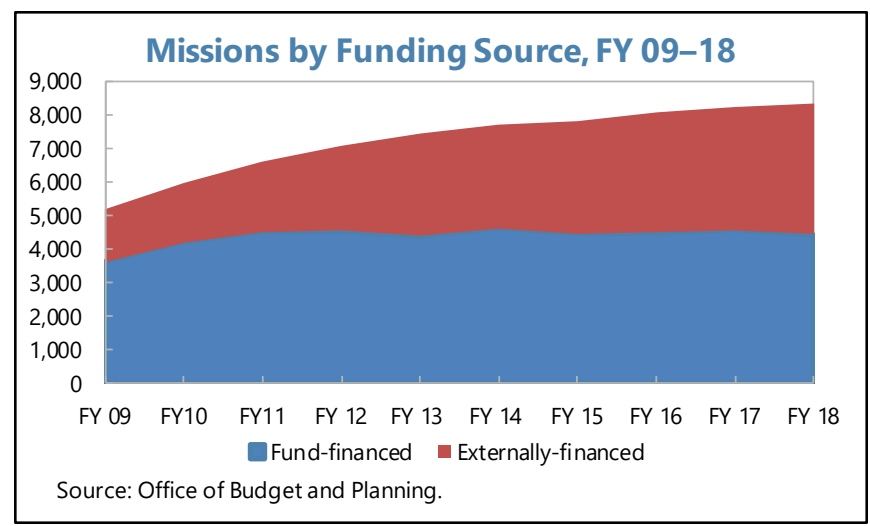

\begin{tabular}{|c|c|c|c|}
\hline \multicolumn{4}{|c|}{ Travel Metrics by Region, FY 16-18 1/ } \\
\hline & FY 16 & FY 17 & FY 18 \\
\hline Number of missions & 8,005 & 8,170 & 8,296 \\
\hline AFR & 1,793 & 1,948 & 1,991 \\
\hline APD & 1,262 & 1,316 & 1,495 \\
\hline EUR & 1,868 & 1,828 & 1,805 \\
\hline MCD & 709 & 744 & 751 \\
\hline WHD & 2,373 & 2,334 & 2,254 \\
\hline Mission nights & 92,979 & 93,668 & 91,255 \\
\hline AFR & 26,178 & 29,345 & 29,172 \\
\hline APD & 15,735 & 16,914 & 16,264 \\
\hline EUR & 20,554 & 17,508 & 16,332 \\
\hline MCD & 10,565 & 11,744 & 11,127 \\
\hline WHD & 19,947 & 18,157 & 18,360 \\
\hline Mission persons & 13,114 & 13,153 & 13,490 \\
\hline AFR & 2,885 & 3,157 & 3,279 \\
\hline APD & 2,077 & 2,242 & 2,418 \\
\hline EUR & 3,318 & 3,073 & 3,133 \\
\hline MCD & 1,329 & 1,395 & 1,375 \\
\hline WHD & 3,505 & 3,286 & 3,285 \\
\hline
\end{tabular}

\footnotetext{
${ }^{6}$ Person days is measured as mission nights relative to the number of missions.
} 


\section{Budgets on IT, buildings and other expenses have been under pressure.}

- Pressures were felt across most categories.

- These included needs such as lease arrangements for swing space during HQ1 renewal (in building occupancy), one-off TransformIT initiatives that will result in significant savings going forward (in IT), external consulting services for various initiatives, security, and continued high demand for corporate services, such as audio visual (AV) and language services (all in contractual services). Differences from approved budget were financed mainly with transitional funding.

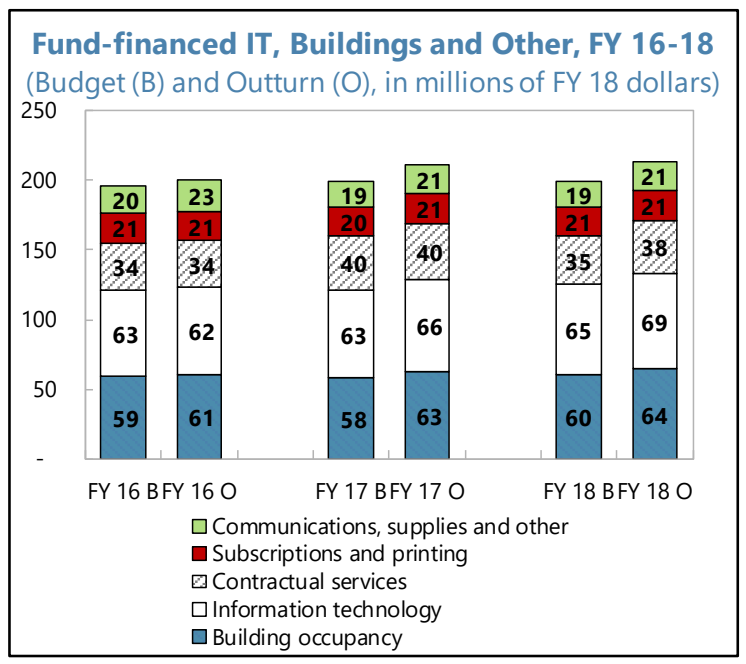

15. Security continued to make up a substantial share of total spending.

- Security-related spending remained at $\$ 36$ million, roughly unchanged from FY 17 .

- Field security costs were lower than previous years. This reflected the absence of overseas security evacuation (for the first time in several years), and lower purchases of armored vehicles. These savings were partially offset by higher physical protection costs.

- Capital expenditures associated with security are discussed below.

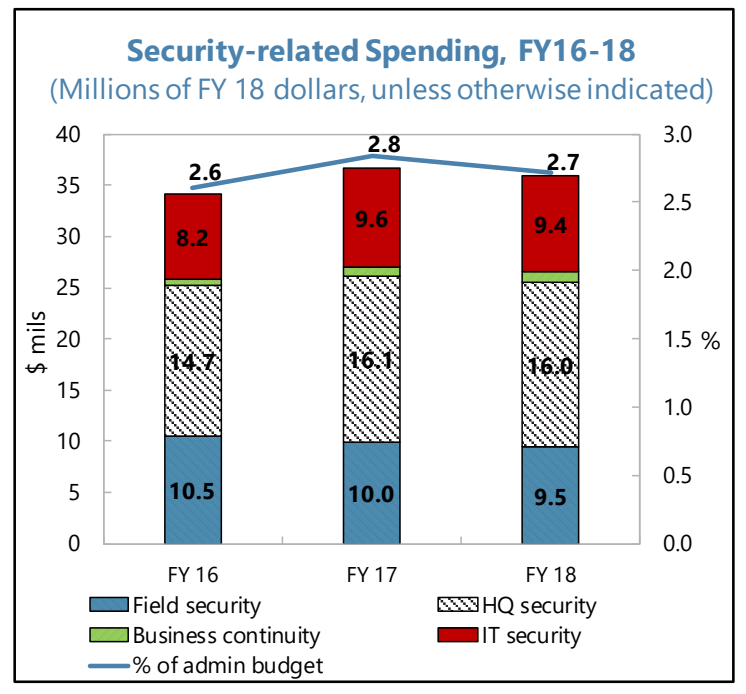

16. The growth in receipts has been driven by reimbursements for externally funded CD.

- Receipts grew considerably. The growth was driven by reimbursements from externally funded CD due to increased activity through regional and thematic vehicles, RCDCs and additional experts in the field.

- General receipts were slightly higher than FY 17 but lower than budget, which was partly due to lower than planned income from Concordia, publications, and reimbursements under cost-sharing agreements with the World Bank, mainly related to the Joint Library.

\begin{tabular}{|c|c|c|c|c|}
\hline \multicolumn{5}{|c|}{$\begin{array}{l}\text { Receipts, FY 16-18 } \\
\text { (Mıllıons of U.S. dollars) }\end{array}$} \\
\hline & \multirow[t]{2}{*}{ FY 16} & \multirow{2}{*}{ FY 17} & \multicolumn{2}{|c|}{ FY 18} \\
\hline & & & \multicolumn{2}{|c|}{ Budget Outturn } \\
\hline & 176 & 189 & 211 & 211 \\
\hline \multicolumn{5}{|l|}{ Externally-financed capacity development (direct } \\
\hline General receipts & 34 & 35 & 39 & 37 \\
\hline \multicolumn{5}{|l|}{ Of which: } \\
\hline Administrative and trust fund management fees $1 /$ & 10 & 11 & 12 & 12 \\
\hline Publications income & 2 & 2 & 2 & 2 \\
\hline Fund-sponsored sharing agreements $2 /$ & 3 & 3 & 4 & 3 \\
\hline HQ2 lease 3/ & 4 & 5 & 4 & 5 \\
\hline Concordia & 3 & 3 & 4 & 3 \\
\hline \multicolumn{5}{|c|}{$\begin{array}{l}\text { Source: Office of Budget and Planning. } \\
\text { Note: Figures may not add to totals due to rounding. } \\
\text { 1/ Trust fund management fee of } 7 \text { percent under the new financing instrument. } \\
\text { 2/ Includes reimbursements principally provided by the World Bank for } \\
\text { administrative services provided under sharing agreements. } \\
\text { 3/ Includes lease of space to the World Bank, Credit Union and retail tenants. }\end{array}$} \\
\hline
\end{tabular}


17. Capital spending totaled $\mathbf{\$ 1 1 6}$ million in FY18 out of the $\$ 303$ million available in appropriations. Remaining unspent funds are primarily related to the HQ1 renewal project and related facilities projects for furniture and AV replacements and upgrades. Additionally, a number of IT multi-year capital projects are in progress, and appropriations for security improvements for HQ facilities are on hold pending feasibility studies.

- HQ1 renewal is on track, with reoccupation through the $9^{\text {th }}$ floor and anticipated completion by Fall 2019.

- $\$ 22$ million was spent on building facilities: mostly AV and furniture, alignins with HQ1 renewal progress.

- $\$ 31$ million was spent in IT investments: protection against cyber security threats, improved data and knowledge management, replacement of aging infrastructure (including personal computer refresh), funding for initial phases of critical projects such as Human Capital Management and document management system replacements.

- Capital expenditures of $\$ 5$ million were incurred for security projects, primarily for continued improvements to guard against cyberattacks (in IT infrastructure).

- While investments in Core, Strategic and Corporate capabilities have changed slightly from year to year, the

\begin{tabular}{|c|c|c|c|c|c|}
\hline \multicolumn{6}{|c|}{$\begin{array}{l}\text { Capital Expenditures, FY } 18 \\
\text { (Millions of U.S. dollars) }\end{array}$} \\
\hline & Facilities & IT & $\begin{array}{l}\text { Iotal } \\
\text { Facilities } \\
\text { and IT }\end{array}$ & $\begin{array}{c}\text { HQ1 } \\
\text { Renewal }\end{array}$ & $\begin{array}{l}\text { Total } \\
\text { Capital }\end{array}$ \\
\hline FY 18 Budget Appropriations & 31 & 35 & 66 & - & 66 \\
\hline + Unspent FY 16 and FY 17 Funding & 39 & 15 & 53 & 183 & 236 \\
\hline = Total funds available in FY $181 /$ & 70 & 50 & 120 & 183 & 303 \\
\hline Expenditures FY 18 & 22 & 31 & 54 & 62 & 116 \\
\hline Expenditures FY 17 & 18 & 28 & 46 & 76 & 122 \\
\hline \multicolumn{6}{|c|}{$\begin{array}{l}\text { Sources: Office of Budget and Planning and Corporate Services and Facilities } \\
\text { 1/ Approved capital funding is available for three consecutive years, except for HQ1 } \\
\text { Renewal which is available until April } 2025 .\end{array}$} \\
\hline
\end{tabular}
increases over the last two years are mainly due to the cyclical refresh of personal computers (shown in IT infrastructure). 


\section{Annex I. Capacity Development ${ }^{1}$}

1. This annex provides additional information on capacity development (CD) activities. It reports on overall spending on $C D$ activities, sources of external financing, $C D$ distribution, and training participation. ${ }^{2}$

\section{A. Overall Spending on CD Activities}

\section{The share of spending on CD has increased steadily since FY09, supported by successful} partnerships. $C D$, which comprises TA and external training, has been the Fund's largest single output since FY12, rising from about 24 percent of total spending in FY12 to about 28 percent in FY17 and 31 percent in FY18. The increase in $C D$ spending over the past five years has been in line with Fund objectives, and continues to reflect growing country demand for $C D$, with $C D$ delivery having been facilitated by greater external financing (Figure 1). ${ }^{3}$

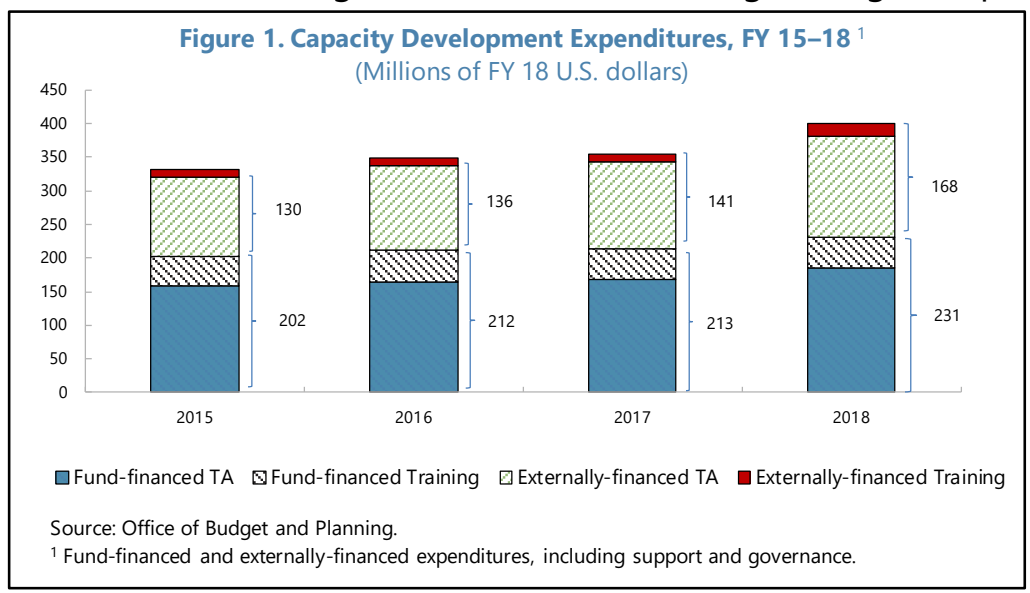

3. Execution rates for externally-financed CD activities rose in FY18 (Table 1). The marginal overrun against budget, in sharp contrast to significant underperformance in earlier years, reflected improved implementation due mainly to fewer disruptions from security and funding delays. Externally-financed direct CD spending grew strongly as a result of higher delivery in RCDCs (including the newly established South Asia Regional Training and Technical Assistance Center, SARTTAC), increased CD in thematic funds, such as the first phase of Resource Mobilization Trust Fund, and sizeable scaling up of CD activities financed by bilateral subaccounts (including China, Japan, the Netherlands, and Switzerland).

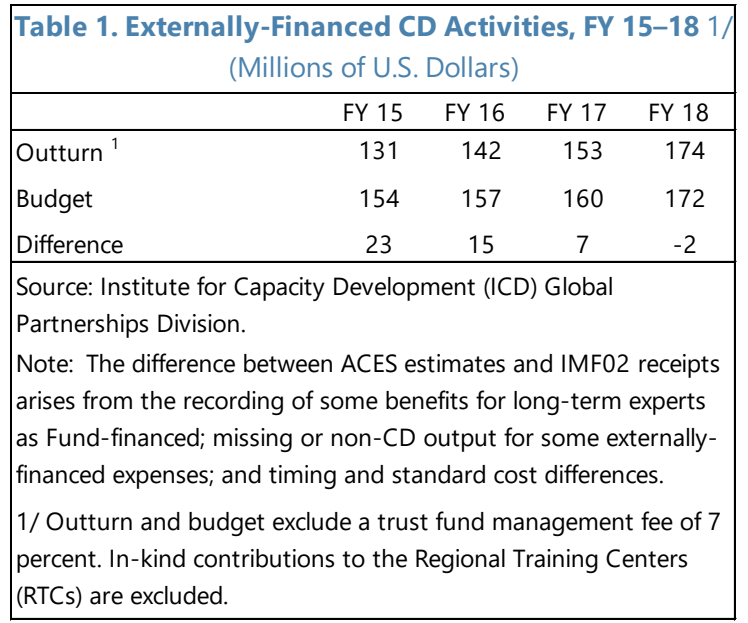

\footnotetext{
${ }^{1}$ Prepared by Lidia Brito, Nathalie Carcenac, Felix Fischer, Yiruo Li, Mercy Pinargote, Wasima Rahman-Garrett, Yan Sun, and Andre Vieira de Carvalho (all ICD).

${ }^{2}$ Different but complementary data sources are used to present information on $C D$, specifically: (i) data on spending on CD activities are from ACES, consistent with the main paper; (ii) data on external financing by development partners comes from the Capacity Development Information Management System (CDIMS), and (iii) data on TA field delivery are drawn from the Travel Information Management System (TIMS), while the training data on number of participants is from the Participant and Applicant Tracking System (PATS).

${ }^{3} \mathrm{CD}$ spending data from ACES, as discussed in the main report, presents a broader view of $C D$ as it reflects spending at headquarters as well as in the field. Overall, CD funded by development partners accounts for about 55 percent of direct spending on CD (excluding support and governance costs) in FY18.
} 


\section{Funding risks related to externally financed CD have been and continue to be actively managed on a range of fronts:}

- Pursuing broader and more sustained partnerships through more active fundraising to a wider range of partners. More diversified partnerships will reduce dependence on large contributors as shortfalls from one partner can be more easily absorbed by the others. Longer and more strategic partnerships provide greater funding certainty over the medium term.

- Increasing flexibility by promoting multi-partner and umbrella agreements that enable the Fund to allocate funding across a range of CD activities.

- Reducing operational risks by (a) securing financing upfront before carrying out CD delivery, and (b) flexibly adjusting the components of a work program if funding falls short. All CD projects or programs have built-in degrees of flexibility to allow adjustments.

\section{CD Distribution}

\section{The broad composition of CD spending across regions and topics is driven by the} demands and needs of member countries and guided by the CD priorities of the Fund. As outlined in the 2014 CD policy statement, Fund policies seek to ensure adequate funding for CD in crisis situations, allowing donor financing when donor interests are consistent with Fund priorities and objectives, and relying on Fund financing when donor support is not available. ${ }^{4}$ The planning and prioritization of $C D$ activities takes place at the institutional level and are informed by IMFC communiques, the Global Policy Agenda, the Fund's work program, and other initiatives discussed by the Executive Board, e.g., on Financing for Development and the Sustainable Development Goals, as well as area departments' Regional Strategy Notes and CD country strategies.

\section{Direct spending on CD was} \$303 million in FY18, reflecting 14 percent growth from FY17 (Table 5). By region, the strongest growth in CD spending was to the Asia and Pacific Department (APD), thanks to SARTTAC coming onstream and increased financing from existing vehicles (an increase in the budget for the Pacific Financial Technical Assistance Center, PFTAC, in its new phase, the recovery in JSA funding, and financing from

\begin{tabular}{|c|c|c|c|c|}
\hline \multicolumn{5}{|c|}{$\begin{array}{c}\text { Table 5. Direct Spending on CD by Region, } \\
\text { Income Group, FY 15-18 } \\
\text { (Millions of U.S. dollars) }\end{array}$} \\
\hline & FY 15 & FY 16 & FY 17 & FY 18 \\
\hline Total & 242 & 256 & 267 & 303 \\
\hline \multicolumn{5}{|l|}{ Region } \\
\hline Sub-saharan Africa & 75 & 79 & 86 & 93 \\
\hline Asia and Pacific & 42 & 41 & 37 & 55 \\
\hline Europe & 22 & 24 & 26 & 28 \\
\hline Middle East and Central Asia & 22 & 26 & 30 & 34 \\
\hline Western Hemisphere & 35 & 36 & 34 & 38 \\
\hline Multiple regions & 35 & 44 & 44 & 45 \\
\hline Non-specific Region & 12 & 7 & 9 & 9 \\
\hline \multicolumn{5}{|l|}{ Income Group 1/ 2/ } \\
\hline $\begin{array}{l}\text { Advanced economies } \\
\text { Emerging market and middle-income }\end{array}$ & 22 & 16 & 17 & 13 \\
\hline economies & 70 & 74 & 73 & 90 \\
\hline Low-income developing countries & 74 & 75 & 83 & 97 \\
\hline Other $3 /$ & 75 & 91 & 93 & 103 \\
\hline \multicolumn{5}{|c|}{$\begin{array}{l}\text { Sources: Monitoring of Fund Arrangements (MONA) database; and Office of } \\
\text { Budget and Planning; Analytic Costing and Estimation System (ACES) } \\
\text { 1/ Spending on CD delivered to regional groups has been distributed evenly } \\
\text { among member countries of each group. }\end{array}$} \\
\hline \multicolumn{5}{|c|}{$\begin{array}{l}\text { 2/ Advanced economies are classified according to the April } 2018 \text { World Economic } \\
\text { Outlook. Low-income developing countries as defined in IMF, Macroeconomic } \\
\text { Developments and Prospects in Low-Income Developing Countries - } 2018 \text {. } \\
\text { Emerging market and middle-income economies include those not classified as } \\
\text { advanced economies or low-income developing countries. }\end{array}$} \\
\hline $\begin{array}{l}\text { 3/ Other includes spending on CD govern } \\
\text { income groups and regional economic in }\end{array}$ & $\begin{array}{l}\text { ance and } \\
\text { titution s }\end{array}$ & $\begin{array}{l}\text { und-raisin } \\
\text { fff. }\end{array}$ & ; $C D$ to & \\
\hline
\end{tabular}

\footnotetext{
${ }^{4}$ IMF Policy and Practices on Capacity Development, August 26, 2014.
} 
RMTF). AFR continues to receive the largest share of $C D$ spending. $C D$ to emerging market and middle-income countries (EMs) and low-income developing countries (LIDCs) grew strongly by about 23 percent and 17 percent respectively in FY18. FAD continues to account for most (37 percent in FY18) of the CD spending, followed by MCM and ICD (Table 6).

\section{Delivery continues to be broadly targeted to the CD priorities (Table 7). Delivery} related to financial market deepening for LICs,

\begin{tabular}{|c|c|c|c|c|}
\hline & FY 15 & FY 16 & FY 17 & FY 18 \\
\hline Total & 242 & 256 & 267 & 303 \\
\hline \multicolumn{5}{|l|}{ Department } \\
\hline Fiscal Affairs Department & 83 & 89 & 96 & 113 \\
\hline Ins. for Capacity Development 1/ & 43 & 44 & 45 & 41 \\
\hline Legal Department & 12 & 12 & 13 & 14 \\
\hline Monetary and Capital Markets & 45 & 49 & 49 & 56 \\
\hline Statistics Department & 28 & 28 & 29 & 36 \\
\hline Other 2/ & 31 & 35 & 35 & 45 \\
\hline
\end{tabular}

Domestic Revenue Mobilization, Public Financial Management, financial supervision and regulation, closing data gaps, and financial integrity experienced the strongest growth. Delivery to fragile states increased almost 9 percent in FY18. Delivery to program countries grew in FY 18 to 40 percent of total, as the number of Fund-supported programs increased.

Table 7. Growth Rate Technical Assistance Delivery to Priority Area, FY 15-18 1/2/ (Person-years)

\begin{tabular}{|c|c|c|c|c|c|}
\hline & \multicolumn{4}{|c|}{ Y-o-Y Growth Rates (\%) } & \multirow{2}{*}{$\begin{array}{l}\text { Share } \\
\text { FY2018 }\end{array}$} \\
\hline & FY 15 & FY 16 & FY 17 & FY 18 & \\
\hline Total & 1.0 & 5.2 & -0.7 & 9.8 & $100 \%$ \\
\hline Fragile states $3 /$ & 4.2 & 1.1 & 2.8 & 8.9 & $28 \%$ \\
\hline \multicolumn{6}{|l|}{ Highly vulnerable countries } \\
\hline Current list (37 countries) & -0.1 & 5.8 & 2.4 & -2.4 & $21 \%$ \\
\hline Historic list (number changes annually) & -0.4 & 46.9 & -13.2 & -25.6 & $21 \%$ \\
\hline (number of countries) & 44 & 57 & 51 & 37 & $\ldots$ \\
\hline \multicolumn{6}{|l|}{ Program countries $4 /$} \\
\hline Current list (46 countries) & 1.1 & 12.5 & 11.4 & 11.2 & $40 \%$ \\
\hline Historic list (number changes annually) & -5.9 & 0.1 & 19.7 & 20.6 & $40 \%$ \\
\hline (number of countries) & 44 & 41 & 44 & 46 & $\ldots$ \\
\hline \multicolumn{6}{|l|}{ Priority topics } \\
\hline Domestic revenue mobilization & -2.6 & 7.2 & 6.9 & 13.8 & $28 \%$ \\
\hline Public financial management & -3.6 & -1.7 & 4.4 & 10.8 & $25 \%$ \\
\hline Financial Market Deepening for LICs 5/ & -38.4 & 42.2 & 8.5 & 19.9 & $3 \%$ \\
\hline $\begin{array}{l}\text { Financial Supervision and Regulation, Fintech and } \\
\text { Monetary Policy Frameworks (ex. AEs) }\end{array}$ & -2.0 & 11.8 & 0.5 & 12.9 & $16 \%$ \\
\hline $\begin{array}{l}\text { Closing Data Gaps, Ratcheting up Data Quality, } \\
\text { Broadening Data Dissemination }\end{array}$ & 15.8 & -9.9 & -7.9 & 9.3 & $12 \%$ \\
\hline Financial integrity (AML/CFT) & -3.5 & 4.3 & 1.1 & 12.2 & $3 \%$ \\
\hline \multicolumn{6}{|c|}{$\begin{array}{l}\text { 1/ An effective person-year of field delivery of technical assistance is defined as } 260-262 \text { working days of Fund staff or experts. } \\
\text { 2/ The priority groups overlap. Compositions of highly-vulnerable and program countries change on annual basis. Financial } \\
\text { supervision and regulation data excludes advanced economies. }\end{array}$} \\
\hline \multicolumn{6}{|c|}{$\begin{array}{l}\text { 3/ Fragile states reflect the IMF lists countries with a World Bank CPIA below 3.20, or presence of UN peacekeeping operations } \\
\text { on the ground, as Fragile and Conflict States. } \\
\text { 4/ Program status from MONA database. A country is classified as a program country if it had a Fund financing or non- } \\
\text { financing arrangement in place at any time during the fiscal year. }\end{array}$} \\
\hline $\begin{array}{l}5 \text { / Includes correspondent banking, debt sustainability, de } \\
\text { management frameworks. }\end{array}$ & hent, ar & egulat & & & \\
\hline
\end{tabular}




\section{Training Participation}

\section{9. $\quad$ Participation in IMF training} grew by 18 percent in FY18 (Table 8). ICD remains the largest provider of training, followed by FAD and STA. Training participation increased across most regions, particularly in APD, reflecting a full year of SARTTAC operations. AFR received the largest share of training at about 28 percent, followed by APD and MCD. Training to participants from EMs and LIDCs grew strongly, with EMs continuing to receive the largest share of training at 55 percent, followed by LIDCs at 38 percent (Table 9).

10. Online learning continues to grow (Table 10). Training under the online learning program started in FY14, and has grown to account for about 30 percent of participants in FY18. The number of online courses offered increased to twenty-two in FY18 from thirteen in FY16. Driven especially by strong growth in AFR and $M C D$, the number of officials trained online grew by over 40 percent in FY18. During FY18, there was a significant increase in training participation for courses in specialized fiscal issues, and monetary, exchange rate, and capital account policies. General macroeconomic analysis continues to be the largest category of courses offered by the Fund, followed by courses on specialized fiscal issues and macroeconomic statistics.

\begin{tabular}{|c|c|c|c|c|}
\hline & FY 15 & FY 16 & FY 17 & FY 18 \\
\hline \multicolumn{5}{|l|}{ Department } \\
\hline Fiscal Affairs Department & 613 & 804 & 1,021 & 1,873 \\
\hline Ins. for Capacity Development & 4,848 & 7,323 & 7,265 & 8,781 \\
\hline Legal Department & 400 & 593 & 481 & 430 \\
\hline Monetary and Capital Markets & 391 & 448 & 367 & 575 \\
\hline Statistics Department & 1,450 & 1,606 & 1,566 & 1,819 \\
\hline Other including RTACs 1/ & 3,736 & 3,736 & 3,168 & 2,932 \\
\hline \multicolumn{5}{|l|}{ Region } \\
\hline Sub-saharan Africa & 2,903 & 3,997 & 4,345 & 4,657 \\
\hline Asia and Pacific & 2,840 & 2,931 & 2,513 & 3,624 \\
\hline Europe & 1,306 & 2,140 & 1,883 & 1,884 \\
\hline Middle East and Central Asia & 2,114 & 2,554 & 2,831 & 3,499 \\
\hline Western Hemisphere & 2,275 & 2,888 & 2,296 & 2,746 \\
\hline Total & 11,438 & 14,510 & 13,868 & 16,410 \\
\hline
\end{tabular}

\begin{tabular}{|c|c|c|c|c|}
\hline \multicolumn{5}{|c|}{$\begin{array}{l}\text { Table 9. Total Training Participation by } \\
\text { Income Group, FY 15-18 } \\
\text { (Number of participants) }\end{array}$} \\
\hline & FY 15 & FY 16 & FY 17 & FY 18 \\
\hline \multicolumn{5}{|l|}{ Income Group } \\
\hline Advanced economies & 700 & 1,044 & 794 & 736 \\
\hline $\begin{array}{l}\text { Emerging market and middle- } \\
\text { income economies }\end{array}$ & 6,087 & 7,831 & 7,334 & 9,056 \\
\hline Low-income developing countries & 4,390 & 5,329 & 5,514 & 6,255 \\
\hline Other ${ }^{1}$ & 261 & 306 & 226 & 363 \\
\hline Total & 11,438 & 14,510 & 13,868 & 16,410 \\
\hline
\end{tabular}


Table 10. Total Training Participation by Venue and Course Group, FY 15-18 (Number of participants)

\begin{tabular}{lrrrr}
\hline & FY 15 & FY 16 & FY 17 & FY 18 \\
\hline Training Venue & & & & \\
Regional Training Centers & 3,751 & 4,084 & 4,142 & 5,500 \\
IMF HQ & 647 & 790 & 719 & 801 \\
Other training locations & 5,552 & 5,757 & 5,637 & 5,249 \\
Online learning 1/ & 1,488 & 3,879 & 3,370 & 4,860 \\
Course Category & & & & \\
Financial Sector Policies & 971 & 1,020 & 1,434 & 1,206 \\
Fiscal Policy & 643 & 1,034 & 1,068 & 798 \\
Specialized Fiscal Issues & 991 & 1,312 & 602 & 1,730 \\
General Macroeconomic Analysis & 2,286 & 4,226 & 3,526 & 4,737 \\
Macroeconomic Statistics & 1,543 & 1,802 & 1,762 & 1,709 \\
Legal courses including AML-CFT & 400 & 625 & 438 & 390 \\
Monetary and Financial Sector & 400 & 742 & 433 & 625 \\
Monetary, Exchange Rate, and Capital Account Policies & 224 & 211 & 410 & 1,031 \\
Safeguards Assessments & 59 & 112 & 58 & 89 \\
Inclusive Growth and Structural Policies & 671 & 768 & 764 & 939 \\
Other Courses & 3,250 & 2,658 & 3,373 & 3,156 \\
\hline Total & $\mathbf{1 1 , 4 3 8}$ & $\mathbf{1 4 , 5 1 0}$ & $\mathbf{1 3 , 8 6 8}$ & $\mathbf{1 6 , 4 1 0}$ \\
Source: Participant and Applicant Tracking System. & & & & \\
Note: FY 18 data are preliminary. & & & & \\
1/ Online learning course volume calculated using conversion factors to estimate the equivalent & \\
number of full training days for each course. & & & & \\
\hline
\end{tabular}

11. Training participation by CD country priority groups was mixed in FY 18 (Table 11). Training participation from fragile states and countries with Fund-supported program grew strongly by about 17 percent and 14 percent, respectively. Training to highlyvulnerable countries also rose sharply by 25 percent.

\begin{tabular}{|c|c|c|c|c|}
\hline \multicolumn{5}{|c|}{$\begin{array}{l}\text { Table 11. Total Training Participation by } \\
\text { Priority Area, FY 15-18 } \\
\text { (Number of participants) }\end{array}$} \\
\hline & FY 15 & FY 16 & FY 17 & FY 18 \\
\hline \multicolumn{5}{|l|}{ Priority Area } \\
\hline Fragile states $1 /$ & 2,410 & 2,785 & 2,910 & 3,401 \\
\hline \multicolumn{5}{|l|}{ Highly-vulnerable countries } \\
\hline Current list (37 countries) & 2,121 & 2,742 & 2,818 & 3,520 \\
\hline Historic list (number changes annually) & 2,700 & 4,717 & 4,032 & 3,520 \\
\hline (number of countries) & 44 & 57 & 51 & 37 \\
\hline \multicolumn{5}{|l|}{ Program countries 2/ } \\
\hline Current list (46 countries) & 3,055 & 4,579 & 4,629 & 5,282 \\
\hline Historic list (number changes annually) & 2,817 & 3,791 & 4,325 & 5,282 \\
\hline (number of countries) & 44 & 41 & 44 & 46 \\
\hline \multicolumn{5}{|c|}{$\begin{array}{l}\text { Sources: Monitoring of Fund Arrangements (MONA) database; and Participant and } \\
\text { Applicant Tracking System. } \\
\text { Note: FY } 18 \text { data are preliminary. } \\
\text { 1/ Fragile states reflect the IMF lists countries with a WB CPIA below 3.20, or presence of } \\
\text { UN peacekeeping operations on the ground, as Fragile and Conflict States. } \\
\text { 2/ Program status from MONA database. }\end{array}$} \\
\hline
\end{tabular}




\section{Annex II. Statistical Tables}

Table 1. Gross Administrative Fund and Externally-financed Spending Estimates by Output 1/

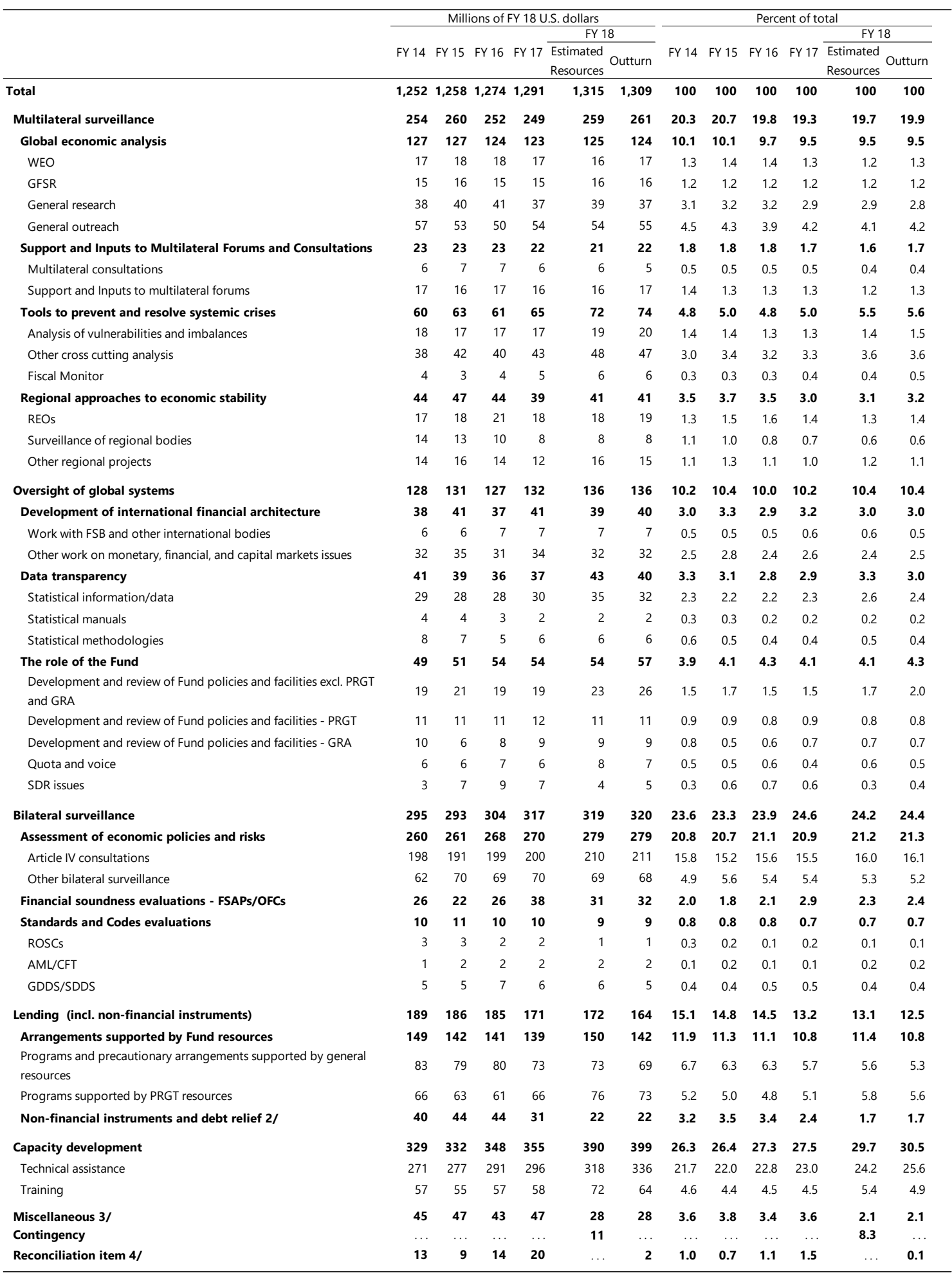

Source: Office of Budget and Planning, Analytic Costing and Estimation System (ACES).

1 / Support and governance costs are allocated to outputs.

2/ Includes Post Program Monitoring (PPM), Policy Support Instruments (PSI), Staff Monitored Program (SMP), Near Programs, Ex-Post Assessments (EPA), Multilateral Debt Relief Initiative-I (MDRI-I), MDRI-II, Heavily Indebted Poor Countries (HIPC), Joint Staff Advisory Note (JSAN), Post Catastrophe Debt Relief (PCDR), Catastrophe Containment Relief Trust (CCRT), and trade 3/ The "Miscellaneous" classification includes expenditures that currently cannot be properly allocated to specific outputs within the ACES model.

4/ Reconciliation to gross administrative expenditures as per the Fund's financial system. 
Table 2. Administrative Expenditures: Budgets and Outturn, FY 02-18

(Millions of U.S. dollars, except where indicated otherwise)

\begin{tabular}{|c|c|c|c|c|c|c|c|c|c|c|}
\hline \multirow{2}{*}{\multicolumn{2}{|c|}{$\begin{array}{l}\text { Financial } \\
\text { Year }\end{array}$}} & \multirow{2}{*}{\multicolumn{2}{|c|}{ Budget }} & \multirow[t]{3}{*}{ Outturn 1/ 2/ } & \multicolumn{2}{|c|}{$\begin{array}{l}\text { Outturn to Budget } \\
\text { Difference }\end{array}$} & \multicolumn{2}{|c|}{$\begin{array}{l}\text { Budget to Budget } \\
\text { Difference }\end{array}$} & \multicolumn{2}{|c|}{$\begin{array}{l}\text { Outturn to Outturn } \\
\text { Difference }\end{array}$} \\
\hline & & & & & \multirow[t]{2}{*}{ Amount } & \multirow{2}{*}{$\begin{array}{l}\text { Percent } \\
\text {. Net Budg }\end{array}$} & \multirow[t]{2}{*}{ Amount } & \multirow[t]{2}{*}{ Percent } & \multirow[t]{2}{*}{ Amount } & \multirow[t]{2}{*}{ Percent } \\
\hline & & & & & & & & & & \\
\hline 2002 & & 695 & & 677 & -19 & -2.7 & 45 & 6.8 & 39 & 6.1 \\
\hline 2003 & & 746 & & 720 & -26 & -3.5 & 51 & 7.3 & 43 & 6.4 \\
\hline 2004 & & 786 & & 748 & -38 & -4.8 & 39 & 5.2 & 28 & 3.8 \\
\hline 2005 & $3 /$ & 850 & & 826 & -24 & -2.8 & 64 & 8.2 & 78 & 10.5 \\
\hline 2006 & & 876 & & 874 & -2 & -0.2 & 26 & 3.1 & 48 & 5.8 \\
\hline 2007 & & 912 & & 897 & -15 & -1.6 & 36 & 4.1 & 23 & 2.6 \\
\hline 2008 & & 922 & & 891 & -32 & -3.4 & 10 & 1.1 & -7 & -0.7 \\
\hline 2009 & & 868 & & 813 & -55 & -6.3 & -54 & -5.9 & -77 & -8.7 \\
\hline 2010 & & 932 & & 863 & -69 & -7.4 & 64 & 7.3 & 50 & 6.2 \\
\hline 2011 & & 953 & & 917 & -36 & -3.8 & 22 & 2.3 & 54 & 6.2 \\
\hline 2012 & & 985 & 4/ & 947 & -38 & -3.9 & 32 & 3.3 & 30 & 3.2 \\
\hline 2013 & & 997 & $5 /$ & 948 & -50 & -5.0 & 13 & 1.3 & 1 & 0.1 \\
\hline 2014 & & 1,007 & $6 /$ & 988 & -19 & -1.8 & 9 & 0.9 & 40 & 4.3 \\
\hline 2015 & & 1,027 & 7/ & 1,010 & -17 & -1.7 & 20 & 2.0 & 21 & 2.2 \\
\hline 2016 & & 1,052 & $8 /$ & 1,038 & -13 & -1.3 & 25 & 2.4 & 29 & 2.8 \\
\hline 2017 & & 1,072 & 9/ & 1,066 & -6 & -0.6 & 21 & 2.0 & 28 & 2.7 \\
\hline 2018 & & 1,104 & $10 /$ & 1,099 & -5 & -0.5 & 31 & 2.9 & 32 & 3.0 \\
\hline \multicolumn{11}{|c|}{ B. Gross Budget } \\
\hline 2002 & & 737 & & 721 & -16 & -2.1 & 47 & 6.8 & 46 & 6.8 \\
\hline 2003 & & 794 & & 764 & -30 & -3.8 & 57 & 7.8 & 43 & 5.9 \\
\hline 2004 & & 838 & & 806 & -31 & -3.7 & 43 & 5.4 & 42 & 5.5 \\
\hline 2005 & $3 /$ & 905 & & 892 & -13 & -1.4 & 68 & 8.1 & 86 & 10.7 \\
\hline 2006 & & 937 & & 930 & -7 & -0.7 & 32 & 3.5 & 38 & 4.3 \\
\hline 2007 & & 980 & & 966 & -14 & -1.5 & 43 & 4.6 & 35 & 3.8 \\
\hline 2008 & & 994 & & 967 & -27 & -2.7 & 14 & 1.4 & 1 & 0.1 \\
\hline 2009 & & 967 & & 885 & -82 & -8.5 & -27 & -2.7 & -82 & -8.5 \\
\hline 2010 & & 1,032 & & 950 & -81 & -7.9 & 65 & 6.7 & 65 & 7.4 \\
\hline 2011 & & 1,075 & & 1,021 & -54 & -5.0 & 43 & 4.2 & 71 & 7.4 \\
\hline 2012 & & 1,123 & $4 /$ & 1,082 & -41 & -3.7 & 48 & 4.5 & 61 & 6.0 \\
\hline 2013 & & 1,159 & $5 /$ & 1,102 & -57 & -4.9 & 35 & 3.2 & 20 & 1.8 \\
\hline 2014 & & 1,186 & $6 /$ & 1,149 & -37 & -3.2 & 27 & 2.3 & 47 & 4.3 \\
\hline 2015 & & 1,224 & 7/ & 1,177 & -46 & -3.8 & 38 & 3.2 & 29 & 2.5 \\
\hline 2016 & & 1,247 & $8 /$ & 1,215 & -33 & -2.6 & 24 & 1.9 & 38 & 3.2 \\
\hline 2017 & & 1,273 & 9/ & 1,255 & -18 & -1.4 & 25 & 2.0 & 40 & 3.3 \\
\hline 2018 & & 1,315 & $10 /$ & 1,309 & -6 & -0.4 & 42 & 3.3 & 54 & 4.3 \\
\hline
\end{tabular}

Source: Office of Budget and Planning.

Note: Figures may not add to total due rounding.

1/ Includes contributions to the SRP service credit buy back program of $\$ 8.0$ million in FY 05 , \$10.0 million in FY 06 ,

$\$ 20.5$ million in FY07, and \$2.1 million in FY 08 and a one off voluntary contribution of \$12 million in FY 09 .

2/ Includes one-off supplementary contribution to the Retired Staff Benefit Investment Account (RSBIA) of \$27 million in FY 09,

$\$ 30$ million in FY 10; $\$ 45$ million in $\mathrm{FY} 11 ; \$ 30$ million in $\mathrm{FY} 12 ; \$ 12$ million in $\mathrm{FY} 13$; $\$ 8$ million in $\mathrm{FY} 16$; and \$2 million in $\mathrm{FY} 17$.

3/ The figures for FY 05 include $\$ 48$ million in the contribution to the Staff Retirement Plan (SRP) following

the Executive Board decision to set contributions at 14 percent of gross remuneration.

4/ Excludes FY 11 carry forward funds of $\$ 34.4$ million.

5/ Excludes FY 12 carry forward funds of $\$ 40.6$ million.

6/ Excludes FY 13 carry forward funds of $\$ 41.9$ million.

7/ Excludes FY 14 carry forward funds of $\$ 41.7$ million.

8/ Excludes FY 15 carry forward funds of $\$ 42.5$ million.

9/ Excludes FY 16 carry forward funds of $\$ 43.2$ million.

10/ Excludes FY17 carry forward funds of $\$ 44.3$ million. 
Table 3. Total Fund Employment, FY 15-18

(Full-time Equivalents (FTEs))

\begin{tabular}{lrrrr}
\hline & FY 15 & FY 16 & FY 17 & FY 18 \\
\hline Total Fund employment & 3,661 & 3,704 & 3,762 & 3,881 \\
$\quad$ Regular and term staff 1/ & 2,784 & 2,835 & 2,890 & 2,923 \\
$\quad$ Of which: & & & & \\
$\quad$ Independent Evaluation Office (IEO) & 15 & 14 & 14 & 15 \\
$\quad$ Office of Executive Directors (OED) & 246 & 244 & 250 & 247 \\
Expert and contractual staff 2/ & 877 & 869 & 872 & 958 \\
\hline
\end{tabular}

Source: Office of Budget and Planning.

1/ Includes Fund-financed and externally-financed FTEs.

2/ Fund-financed and externally-financed experts (including short term experts), contractual staff, visiting scholars, secretarial support staff, paid overtime, and other.

Table 4. Departmental Business and Seminar Travel Expenditures, FY 16-18 (Millions of U.S. dollars)

\begin{tabular}{lrrr}
\hline & FY $161 /$ & FY 17 & FY 18 \\
\hline By type of cost & $\mathbf{1 0 8}$ & $\mathbf{1 0 3}$ & $\mathbf{1 1 0}$ \\
Transportation & 62 & 60 & 65 \\
Per diem & 45 & 43 & 45 \\
By type of financing & $\mathbf{1 0 8}$ & $\mathbf{1 0 3}$ & $\mathbf{1 1 0}$ \\
Fund-financed & 70 & 64 & 65 \\
Externally-financed & 38 & 39 & 45 \\
By department & $\mathbf{1 0 8}$ & $\mathbf{1 0 3}$ & $\mathbf{1 1 0}$ \\
Area & 29 & 28 & 30 \\
TA functional & 56 & 59 & 63 \\
Other functional & 6 & 6 & 6 \\
Support & 9 & 5 & 5 \\
Governance & 9 & 5 & 5 \\
OED and IEO & 7 & 5 & 5 \\
Memorandum item: & & & \\
In percent of total gross expenditures & 8.9 & 8.2 & 8.4 \\
\hline Source: Office of Budget and Planning. & & & \\
1/ Includes Annual Meetings travel of approximately $\$ 3.8$ million. & & \\
\hline
\end{tabular}




\begin{tabular}{|crrr|}
\hline \multicolumn{4}{c}{ Table 5. Travel Metrics by Department Type, FY16-18 1/ } \\
\hline & FY 16 & FY 17 & FY 18 \\
\hline Number of missions & $\mathbf{8 , 0 0 5}$ & $\mathbf{8 , 1 7 0}$ & $\mathbf{8 , 2 9 6}$ \\
Area & 1,405 & 1,370 & 1,366 \\
TA Functional & 4,790 & 4,960 & 5,121 \\
Functional & 984 & 1,001 & 989 \\
Support \& Governance & 826 & 839 & 820 \\
Mission nights & & $\mathbf{9 3 , 6 6 8}$ & $\mathbf{9 1 , 2 5 5}$ \\
Area & $\mathbf{9 2 , 9 7 9}$ & 24,722 & 24,115 \\
TA Functional & 25,931 & 60,939 & 59,762 \\
Functional & 57,413 & $\mathbf{4 , 5 6 0}$ & 3,781 \\
Support \& Governance & 6,067 & 3,447 & 3,597 \\
Area & 3,568 & $\mathbf{1 3 , 1 5 3}$ & $\mathbf{1 3 , 4 9 0}$ \\
TA Functional & $\mathbf{1 3 , 1 1 4}$ & 3,557 & 3,605 \\
Functional & 3,827 & $\mathbf{7 , 2 5 2}$ & $\mathbf{7 , 5 8 4}$ \\
Support \& Governance & 6,987 & 1,203 & 1,169 \\
Mission persons & 1,207 & 1,141 & 1,132 \\
\hline 1/ Excludes Annual Meetings, IEO, OED. & 1,093 & & \\
\hline
\end{tabular}


Table 6. Capital Expenditures, FY12-18

(Millions of U.S. dollars)

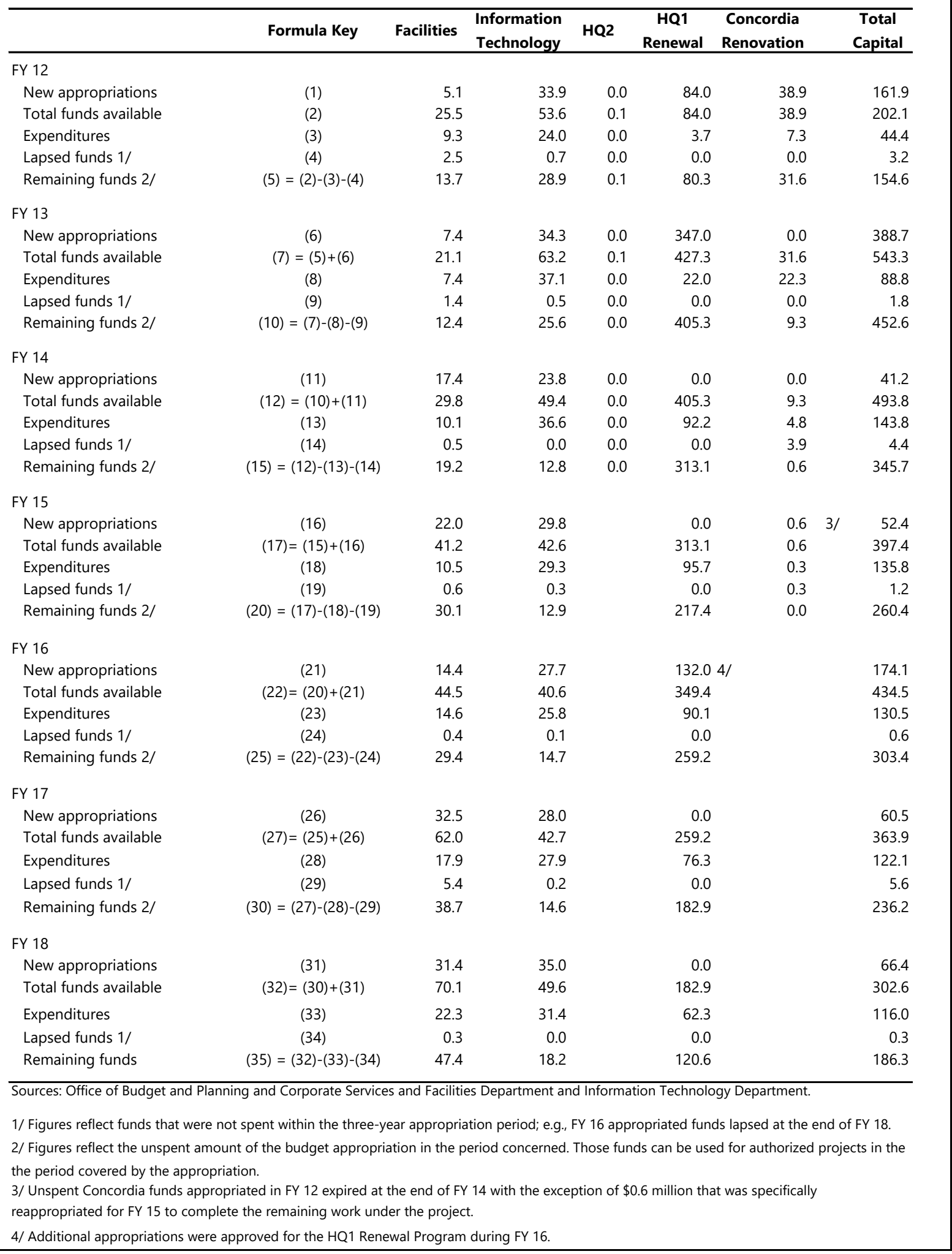

